\title{
Relationship Between Structure And Antimicrobial Activity Of Zinc Oxide Nanoparticles: An Overview
}

This article was published in the following Dove Press journal:

International Journal of Nanomedicine

\author{
Bruna Lallo da Silva (D) \\ Marina Paiva Abuçafy (D) ${ }^{\prime}$ \\ Eloisa Berbel Manaia (D) \\ João Augusto Oshiro Junior (ID ${ }^{1}$ \\ Bruna Galdorfini \\ Chiari-Andréo (D) ${ }^{1,2}$ \\ Rosemeire CL R Pietro (D) \\ Leila Aparecida Chiavacci (ID) \\ 'Department of Drugs and Medicines, \\ School of Pharmaceutical Sciences, São \\ Paulo State University (UNESP), \\ Araraquara, SP, Brazil; ' 2 Department of \\ Biological and Health Sciences, \\ Universidade De Araraquara, UNIARA, \\ Araraquara, SP, Brazil
}

Correspondence: Leila Aparecida Chiavacci

Department of Drugs and Medicines, School of Pharmaceutical Sciences, São Paulo State University (UNESP), Rodovia

Araraquara Jaú, km I - s/n Campos Ville, Araraquara, SP, Brazil

Tel +55 1633016966

Fax +55 16 33016900

Email leila@fcfar.unesp.br

\begin{abstract}
The inappropriate use of antimicrobials has resulted in the selection of resistant strains. Thus, a great number of studies have focused on the investigation of new antimicrobial agents. The use of zinc oxide nanoparticles ( $\mathrm{ZnO}$ NPs) to optimise the fight against microbial resistance has been receiving increased attention due to the non-specific activity of inorganic antimicrobial agents. The small particle size and the high surface area of ZnO NPs can enhance antimicrobial activity, causing an improvement in surface reactivity. In addition, surface modifiers covering $\mathrm{ZnO}$ NPs can play a role in mediating antimicrobial activity since the surface properties of nanomaterials alter their interactions with cells; this may interfere with the antimicrobial effect of ZnO NPs. The possibility of using surface modifiers with groups toxic to microorganisms can improve the antimicrobial activity of $\mathrm{ZnO}$ NPs. Understanding the exact toxicity mechanisms is crucial to elucidating the antimicrobial activity of $\mathrm{ZnO}$ NPs in bacteria and fungi. Therefore, this review aims to describe the mechanisms of ZnO NPs toxicity against fungi and bacteria and how the different structural and physical-chemical characteristics of $\mathrm{ZnO}$ NPs can interfere in their antimicrobial activity.
\end{abstract}

Keywords: nanoparticles, zinc oxide, antimicrobial activity, toxicity mechanisms

\section{Introduction}

The inappropriate use of antimicrobials has resulted in the emergence of multidrugresistant strains, causing an increase in infectious disease and mortality. ${ }^{1,2}$ Bacterial resistance may be generated by genetic mutations arising from adaptive responses or via horizontal gene transfer $(\mathrm{HGT}){ }^{3}$ HGT can occur by conjugation, which requires cell-cell contact across the cell surface pili or adhesins (elements present in the cellular structure of some bacteria), through which the DNA is transferred by plasmids from the donor cell to the recipient cell. For example, $\beta$-lactamases have been found to be transmitted by plasmids and are capable of being transferred between bacterial species. ${ }^{4}$ In the same way, the prolonged and intense use of antifungal compounds has led to decreased sensitivity and increased numbers of strains resistant to miconazole, fluconazole and amphotericin-B. These drugs are still considered the best standards for the treatment of severe mycoses, but severe adverse effects such as chronic toxicity limit the use of these drugs due to renal function impairment. ${ }^{5}$ Another important resistance mechanism is biofilm production. Biofilms are found adhered to a solid surface and are composed of an array that covers a community of bacterial cells and protects them from the action of antibiotics. $^{6}$ 
Commonly used antimicrobials act by inhibiting essential components to maintain microbial metabolism, such as cell wall synthesis (beta-lactams, glycopeptides), proteins (aminoglycosides, macrolides, chloramphenicol), DNA (quinolones, coumarins), RNA (rifamycins) and intermediate metabolism (sulphonamides and trimetropine). ${ }^{7}$ However, one of the main challenges of biomedical researchers is to develop antibacterial drugs that are able to combat biofilm-forming and multidrug-resistant strains.

Based on this problem, the use of nanomaterials as antimicrobial agents is justified. This is because the areas in which antibiotics fail can be filled by using nanomaterials in a number of ways: overcoming the mechanisms of microbial resistance through membrane disruption or impeding biofilm formation, or stopping microbial growth using multiple mechanisms of action simultaneously. This is due to the fact that most antibiotic resistance mechanisms do not correspond to the same pathways in which nanomaterials act. ${ }^{8}$ In this sense, the use of inorganic nanoparticles can be an alternative to minimise microbial resistance and to reduce toxicity to human cells. ${ }^{9}$ Recent advances in nanotechnology have enabled the production of particles with various sizes, shapes and a large surface area relative to volume, allowing for interactions with bacterial cells. This has led to the development of new biocidal agents. ${ }^{10}$

Zinc oxide $(\mathrm{ZnO})$, titanium dioxide and silver are used in different areas to control microbial growth. ${ }^{11}$ However, $\mathrm{ZnO}$ has greater advantages because it has the highest photocatalytic efficiency among all the inorganic photocatalytic materials and is more biocompatible than titanium dioxide. Additionally, $\mathrm{ZnO}$ has greater selectivity, better durability and heat resistance, it can be used to combat a diversity of microorganisms, such as $S$. aureus, ${ }^{9,12,13}$ E. coli ${ }^{14}$ and C. albicans. ${ }^{15-17}$

$\mathrm{ZnO}$ is a semi-conductor presenting a high bandgap of $3.4 \mathrm{eV}$ and binding energy of $60 \mathrm{meV}$, leading to peculiar electrical and optical properties. ${ }^{18-20}$ As an antimicrobial agent, $\mathrm{ZnO}$ has been investigated on the microscale and nanoscale. $^{17} \mathrm{~A}$ decrease in $\mathrm{ZnO}$ particle size causes changes in the electrical, optical and chemical properties; some authors believe that these changes are caused by the quantum confinement surface, thus enabling new applications. $^{21}$ For instance, when the size of $\mathrm{ZnO}$ is reduced to the nanoscale, its activity against microorganisms is increased. ${ }^{17}$ Particularly in terms of antimicrobial applications, among the advantages of using an inorganic material rather than an organic material are reduced toxicity, improved durability, lower resistance and good selectivity. ${ }^{2,22}$ Recent studies have demonstrated that
ZnO NPs are efficient at combating multidrug-resistant bacteria $^{23}$ and preventing biofilm formation. ${ }^{24}$

The mechanism of $\mathrm{ZnO}$ NP toxicity depends on the modification of the surface, the intrinsic physicochemical properties of $\mathrm{ZnO}$ and the medium used to disperse the NPs. Several studies have investigated the mechanisms of action of $\mathrm{ZnO}$ NPs on bacteria and fungi, but these studies have not been conclusive. ${ }^{12,25-28}$

As previously mentioned, the use of ZnO NPs may be a promising alternative to minimising microbial resistance. In addition, it is possible to produce $\mathrm{ZnO}$ NPs with various sizes, shapes and surface modifications. Therefore, this review aims to summarise the mechanisms of action described in the literature and how the physicochemical properties and surface modifications of $\mathrm{ZnO}$ may alter their antimicrobial activity. Thus, this review may help to clarify the most desirable $\mathrm{ZnO}$ NP characteristics to achieve the optimal antimicrobial effect.

\section{Mechanism Of Antibacterial Activity Of $\mathrm{ZnO}$ NPs}

To better understand how the structural parameters of $\mathrm{ZnO}$ NPs could alter their antimicrobial activity, this section will describe the main mechanisms of action found in the literature. It is important to highlight that many studies have addressed this theme. However, as nanoparticles act in a non-specific manner, more than one mechanism may explain their activity, which makes the interpretation of the main mechanism responsible for antimicrobial activity more difficult.

$\mathrm{ZnO}$ aqueous suspensions allow for chemical interactions between hydrogen peroxide and the proteins of the cell membrane. Thus, the different chemical species formed explain the different antimicrobial activities. ${ }^{29,30}$

The proposed mechanisms are (i) the production of reactive oxygen species (ROS); $;^{2,12,29-31}$ (ii) the loss of cellular integrity following contact between $\mathrm{ZnO}$ NPs and the cell wall; ${ }^{32,33}$ (iii) the release of $\mathrm{Zn}^{2+}$ ions ${ }^{16,34,35}$ and (iv) $\mathrm{ZnO}$ NPs internalisation. ${ }^{32}$

The production of ROS by metal oxide NPs is one of the mechanisms responsible for antimicrobial activity most commonly reported in the literature. ROS include superoxide anions $\left(\mathrm{O}_{2}{ }^{-}\right)$, hydroxyl radicals $\left(\mathrm{HO}_{2}^{-}\right)$and hydrogen peroxide $\left(\mathrm{H}_{2} \mathrm{O}_{2}\right),{ }^{2,31}$ which can cause the destruction of cellular components such as DNA, proteins and lipids. ${ }^{29,30}$

The ROS production mechanisms driven by $\mathrm{ZnO}$ NPs are described in Figure 1. As a semiconductor, the electronic structure of the $\mathrm{ZnO}$ consists of a conduction band 


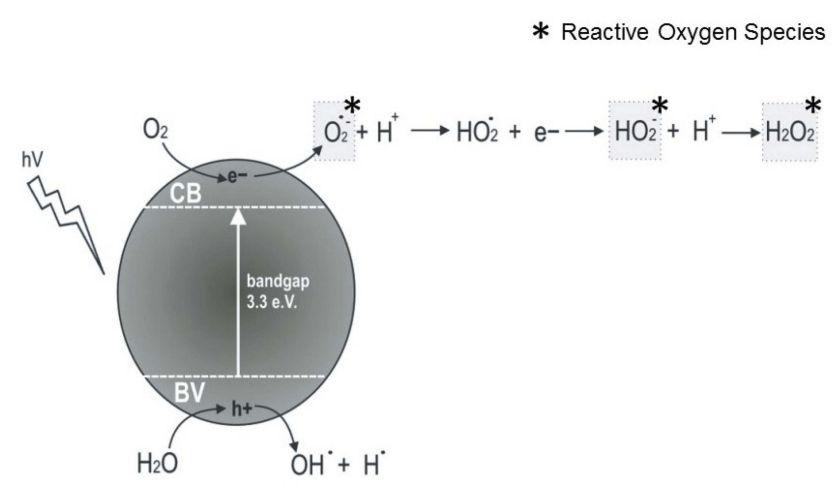

Figure I Formation of reactive oxygen species by $\mathrm{ZnO}$ NPs.

(CB) and a valence band (VB). Photon radiation (hv) with greater energy than the bandgap, ie, higher than $3.3 \mathrm{eV}$, is immediately absorbed and electrons leave the VB by passing to the $\mathrm{CB}$, which initiates a series of photoreactions. ${ }^{36}$ Positive holes $\left(\mathrm{h}^{+}\right)$are formed in the VB and, in turn, there are free electrons $\left(\mathrm{e}^{-}\right)$in the $\mathrm{CB}$. These electron pairs initiate various reactions. The "holes" separate water molecules into $\mathrm{OH}^{-}$and $\mathrm{H}^{+}$. Dissolved oxygen molecules react with the free electron pair of the $\mathrm{CB}$ and are transformed into superoxide radical anions $\left(\mathrm{O}_{2}{ }^{-}\right)$, which react with $\mathrm{H}^{+}$and generate $\left(\mathrm{HO}_{2}\right)$ radicals that after colliding with the electrons $\left(\mathrm{e}^{-}\right)$are transformed into hydroxyl peroxide anions $\left(\mathrm{HO}_{2}{ }^{-}\right)$. These, in turn, can react with hydrogen ions and produce hydrogen peroxide $\left(\mathrm{H}_{2} \mathrm{O}_{2}\right)$ that can penetrate into the cell and kill microorganisms. ${ }^{2,30,31,36}$

Raghupathi and co-workers ${ }^{12}$ attributed the increased antibacterial activity of $\mathrm{ZnO}$ NPs with increased ROS production by NPs after exposure to UV light. However, some studies have shown that ROS can be created even without light exposure. ${ }^{37,38}$ Hirota et $\mathrm{al}^{38}$ developed $\mathrm{ZnO}$ ceramics with sustainable antibacterial activity. The analyses of electron spin resonance and chemical photoluminescence showed that the antibacterial activity of $\mathrm{ZnO}$ could be attributed to superoxide anion production on the $\mathrm{ZnO}$ surface, even under dark conditions. The bacterial cell wall has negative charges, like hydroxyl radicals and superoxides, so they cannot penetrate the membrane, but direct contact can cause damage. Therefore, these species can be found only outside the bacterium. Conversely, hydrogen peroxide is able to pass through the cell wall and can be internalised in the bacterial cell, triggering cell death. ${ }^{2,31,33}$

D'Água et $\mathrm{al}^{39}$ showed that bacteria that were more sensitive to hydrogen peroxide were also the more sensitive to ZnO NPs. Similar results were obtained with less sensitive bacteria. In this way, the authors suggested that peroxide hydrogen could be the mechanism responsible for the antibacterial activity of $\mathrm{ZnO}$ NPs.

Kadiyala et $\mathrm{al}^{40}$ recently studied the antibacterial mechanism of ZnO NPs against methicillin-resistant $S$. aureus. Contrary to studies demonstrating that the antimicrobial activity is dependent on the ROS or Zn ions, in this study, ROS toxicity was not the principal mediator of antibacterial activity. The most relevant parameters to explain the activity of $\mathrm{ZnO}$ NPs were mechanisms that involved pyrimidine, sugar metabolism and amino acid biosynthesis.

Another mechanism that may be responsible for damage to microorganisms is photoconductivity, which is a process of photo-induction. ${ }^{36}$ Due to its semiconductor properties, $\mathrm{ZnO}$ has high photocatalytic efficiency; this can contribute to its antimicrobial effect. ${ }^{17,31}$ Therefore, when $\mathrm{ZnO}$ is submitted to UV light, the antimicrobial effect can be optimised due to the improvement in conductivity, which activates the interactions between $\mathrm{ZnO}$ and bacterial cells. Moreover, when the UV light is turned off, conductivity persists. ${ }^{17}$

Another mechanism that can kill bacteria is the release of $\mathrm{Zn}^{2+}$ ions. When $\mathrm{ZnO}$ NPs are in solution, partial dissolution results in the release of $\mathrm{Zn}^{2+}$ ions, which have antimicrobial activity. Therefore, the dissolution of $\mathrm{ZnO} N$ Ps contributes to its antimicrobial activity ${ }^{16,34}$ by decreasing amino acid metabolism and perturbing the enzymatic system. ${ }^{17}$

Under acidic conditions, ZnO NPs dissolve and produce $\mathrm{Zn}^{2+}$ ions. Based on this dissolution, Cho et al ${ }^{41}$ conducted studies on rats and showed that $\mathrm{ZnO}$ NPs remain intact at neutral or biological $\mathrm{pH}$. However, they rapidly dissolve under acidic conditions ( $\mathrm{pH} 4.5$ ), for example, in a microorganism's lysosomes, leading to death due by binding to the biomolecules inside the bacterial cell and inhibiting its growth.

Li et $\mathrm{al}^{35}$ evaluated the toxicity of $\mathrm{ZnO}$ NPs in E. coli, correlating the release of $\mathrm{Zn}^{2+}$ according to the medium used to disperse them. The media used were ultrapure water, $0.85 \%$ $\mathrm{NaCl}$, phosphate-buffered saline (PBS), minimal Davis (MD) and Luria-Bertani (LB). The results showed that a smaller concentration of $\mathrm{Zn}^{2+}$ in the medium resulted in lower toxicity of NPs against $E$. coli. For example, in PBS, precipitate generation was observed; zinc complexes like citrate-zinc and amino acid-zinc were formed in MD and LB, respectively. These species drastically reduced the $\mathrm{Zn}^{2+}$ ion concentration, which resulted in lower toxicity in these media. The authors concluded that toxicity of $\mathrm{ZnO}$ NPs was found in the following order: ultrapure water $>\mathrm{NaCl}>\mathrm{MD}>\mathrm{LB}>\mathrm{PBS}$. 
In contrast, $\mathrm{Li}$ and co-workers ${ }^{42}$ measured the antibacterial activity of ZnO NPs according to ROS production and $\mathrm{Zn}^{2+}$ ions released by the $\mathrm{ZnO} \mathrm{NP}$ suspensions. The researchers observed that, in the case of a $\mathrm{Zn}^{2+}$ concentration of about $1 \mathrm{mg} / \mathrm{L}$, there was no inhibition of $E$. coli. However, the growth rate of $E$. coli decreased with increasing ROS levels, showing that the released $\mathrm{Zn}^{2+}$ ions had a smaller effect.

Baek and $\mathrm{An}^{27}$ also obtained results contrasting those presented by $\mathrm{Li}$ et al. ${ }^{35}$ The release of free ions by various NPs was studied, including $\mathrm{ZnO}$ NPs. For this purpose, they used strains of E. coli, B. subtilis and S. aureus. The maximum fraction of metal ions that can be released by NPs was used in the experiment. At a concentration of $125 \mathrm{mg} / \mathrm{mL}$ of $\mathrm{ZnO} \mathrm{NPs}, 6.8 \mathrm{mg} / \mathrm{mL}$ of zinc ions were released; thus, the bacteria were placed in contact with the ions and the antibacterial activity was assessed. The results showed that, in the evaluation of free ion activity, inhibition was low (from $2 \%$ to $3 \%$ for all strains tested), but the ZnO NPs showed high toxicity for all strains tested. Thus, the authors suggested that NPs activity may be related to intrinsic metal particle toxicity.

Another possible toxicity mechanism of ZnO NPs corresponds to the interaction of the $\mathrm{ZnO}$ particle with the cell wall, resulting in the loss of bacterial integrity. ${ }^{16,32}$ Brayner et al ${ }^{32}$ evaluated the toxicological impact of ZnO NPs against $E$. coli. The results showed that the bacteria cells were damaged, leading to disorganisation of the membrane; therefore, there was an increase in membrane permeability, leading to the accumulation of $\mathrm{ZnO}$ NPs in the bacterial cell membrane as well as the internalisation of NPs. Similar results were observed by Lallo da Silva et $\mathrm{al}^{43}$ with $S$. aureus, ie, after contact with $\mathrm{ZnO}$ NPs, cells have holes in the membrane.

As previously reported, the toxicity of ZnO NPs is not always dependent on their internalisation in the bacterial cell. ZnO NPs can cause changes in the environment close to the bacteria, ie, producing ROS or increasing the solubility of ZnO NPs, which can induce cellular damage. ${ }^{25,44}$ Figure 2 schematically shows the possible toxicity mechanisms of $\mathrm{ZnO}$ NPs.

Possible mechanisms of the antifungal activity of $\mathrm{ZnO}$ NPs are also described in the literature. ZnO NPs may enter the cell by diffusion and endocytosis; once in contact with the cytoplasm, they interfere in the functioning of mitochondria, promoting the release of ROS and $\mathrm{Zn}^{2+}$. These released ions can penetrate the membrane and reach the DNA, causing nuclear damage like irreversible chromosome damage, which induces cell death. ${ }^{28}$

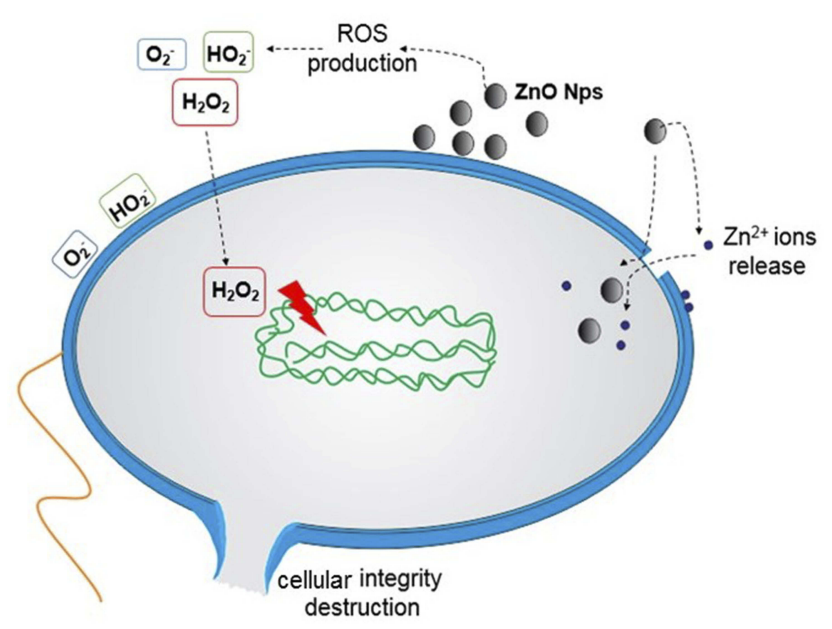

Figure 2 Suggested mechanisms of action of ZnO NPs against bacteria. (I) ZnO NPs release $\mathrm{Zn}^{2+}$ ions, which can be internalised into the bacterial cell and disrupt the enzymatic system. (2) ROS production (causing the destruction of cellular components such as DNA, proteins and lipids): $\mathrm{O}_{2}{ }^{-}$and $\mathrm{HO}_{2}{ }^{-}$(do not penetrate the membrane, but direct contact causes damage) and $\mathrm{H}_{2} \mathrm{O}_{2}$ (internalised). (3) Internalisation within the bacteria cell and direct contact cause damage such as the loss of cellular integrity.

He et al ${ }^{45}$ studied the antifungal activity and ZnO NPs against B. cinerea and P. expansum. Scanning electron microscopy (SEM) and Raman spectroscopy were used to assess morphological changes and cellular composition of hyphae after treatment with ZnO NPs. Inhibition of the both fungi was achieved; however, $P$. expansum was more sensitive. For $B$. cinerea, hyphae malformation was observed, suggesting inhibition by affecting cell function and causing increased nucleic acids derived from the hyphae in response to oxidative stress. In contrast, $\mathrm{ZnO}$ NPs inhibited the development of conidiophores and conidia of P. expansum. These differences in susceptibility may have been caused by the inherent tolerance of each fungus or differences in morphological growth. Indeed, $P$. expansum grows more densely on the surface of the agar, leading to better exposure to $\mathrm{ZnO}$ NPs.

Lipovsky et al ${ }^{46}$ studied the antifungal activity of $\mathrm{ZnO}$ NPs mediated by ROS against Candida albicans. Histidine removes oxygen radicals, and therefore it was added into the culture of $C$. albicans in order to assess the inhibitory effect on toxicity mediated by $\mathrm{ZnO}$ NPs. The results showed that $5 \mathrm{nM}$ histidine inhibited the antifungal effect of $\mathrm{ZnO}$. Thus, the authors suggested that the release of ROS in aqueous media may be responsible for cell death. In addition, in contact with visible light, $\mathrm{ZnO}$ NPs provoked an increase in the cell death rate.

It has been found that the antimicrobial activity of $\mathrm{ZnO}$ NPs is proportional to the NPs concentration; ${ }^{14,15,28}$ 
moreover, the level of ROS released by ZnO NPs is also dose-dependent. ${ }^{28}$

Pasquet et $\mathrm{al}^{26}$ suggested that the antimicrobial activity of $\mathrm{ZnO}$ NPs in fungi may be lower when compared to bacteria since the fungus has the ability to develop pores in hostile conditions. $\mathrm{ZnO}$ demonstrated only fungistatic activity at all NPs concentration used and it did not decrease the initial population. In contrast, a study performed by Eskandari et $\mathrm{al}^{47}$ showed that $\mathrm{ZnO}$ nanorods not only decrease the growth of $C$. albicans but also have fungicidal activity.

$\mathrm{ZnO}$ NPs have Gram-positive and Gram-negative antibacterial activity and antifungal activity ${ }^{48}$ however, the strength of the effect depends on the sensitivity of the microorganism. ${ }^{49}$ A study performed by Shinde et $\mathrm{al}^{50}$ on the antimicrobial activity of $\mathrm{ZnO}$ microspheres (MS-ZnO) against $S$. aureus and $E$. coli suggested that the difference in susceptibility of MS-ZnO in the two bacteria may be explained by the differences in their cell wall. The cell wall of Gram-positive bacteria consists of a thick layer of peptidoglycan $(20-80 \mathrm{~nm})$, which provides a physical barrier that serves to protect the environment of the cell. This thick layer of peptidoglycan also is responsible for fixing polymers such as teichoic and lipoteichoic acids and surface proteins. ${ }^{49,51}$ Gram-negative bacteria have a cell wall with a complex organisation. There is a thin peptidoglycan layer and an external membrane that contain lipopolysaccharides. The external membrane and peptidoglycan are linked by lipoproteins. The peptidoglycan layer is located in the periplasmic space that is formed between the external membrane and the cytoplasmic membrane. ${ }^{25,32,52}$ The cell wall is responsible for maintaining the osmotic pressure and the shape of the cell. NPs of various sizes can easily pass through the layer of peptidoglycan and therefore are highly capable of causing damage. ${ }^{17}$ The peptidoglycan layer contains repeated units of amino acids and carbohydrates. Thus, ZnO NPs can interact with carboxylic acid and amino groups and thereby inhibit cellular processes. However, the peptidoglycan layer of Gram-negative bacteria is thinner than the membrane of Gram-positive bacteria, so rupture of the cell membrane is easier. ${ }^{50}$

The difference between the components of Gram-positive and Gram-negative cell walls was elucidated in a study conducted by Tayel and co-workers. ${ }^{53}$ These researchers suggested that Gram-positive bacteria are more susceptible to attack by $\mathrm{ZnO}$ NPs than Gram-negative bacteria. The minimum inhibitory concentration (MIC) of ZnO NPs observed by Reddy et $\mathrm{al}^{54}$ in $S$. aureus, a Gram-positive bacterium, and E. coli, a Gram-negative bacterium, was $1 \mathrm{mg} / \mathrm{mL}$ and $3.4 \mathrm{mg} / \mathrm{mL}$, respectively, which shows that the inhibition of Gram-negative bacteria requires higher concentrations of $\mathrm{ZnO}$ NPs. This is likely because the peptidoglycan layer that surrounds Gram-positive bacteria can promote $\mathrm{ZnO}$ attack inside the cell, while the cell wall components of Gram-negative bacteria, such as lipopolysaccharides, can counter this attack. Similar results were found by d'Agua et al, ${ }^{39}$ using the agar diffusion method to evaluate the antibacterial activity of textiles containing $\mathrm{ZnO}$ NPs. In this study, the authors showed that Gram-positive bacteria were more sensitive to peroxide hydrogen than Gram-negative bacteria.

Bacteria present the intrinsic ability to produce some substances that induce resistance to oxidative stress. Sphaphyloxantin is a carotenoid produced by the membrane of $S$. aureus that functions as an antioxidant. Thus, DNA, proteins and lipids are better protected against oxidative stress due to the presence of sphaphyloxantin. ${ }^{55}$ Cytochrome oxidase is an enzyme present in some bacteria that can interfere in the antibacterial activity of ZnO NPs because it directly reduces the amount of oxygen present in the water. In the absence of cytochrome oxidase, oxygen reduction makes use of catalase, which involves more stages. This discussion was approached by Pasquet et $\mathrm{al}^{26}$ who observed better activity of ZnO NPs in E. coli than P. aeruginosa, which possesses both cytochrome oxidase and catalase whereas $E$. coli possesses only catalase. Thus, E. coli catalase is involved in oxygen reduction in water whereas P. aeruginos a catalase is readily available for $\mathrm{H}_{2} \mathrm{O}_{2}$ reduction because it is supplemented by cytochrome oxidase. The bacterial growth rate is another factor that can change the bacterial tolerance to $\mathrm{ZnO}$ NPs. Bacteria with a slow growth are less susceptible to the action of antibiotics compared to those with rapid growth. ${ }^{25,56}$

Based on the studies described in this section, it can be concluded that the positive aspects of using ZnO NPs to combat microbial growth make them promising alternatives for combating multidrug-resistant organisms. This is due to the fact that NPs act in a non-specific manner and can thus act on pathways that antibiotics fail to target. Moreover, the main mechanisms of antibiotic resistance are irrelevant to nanoparticles, because the mechanisms do not necessarily involve NPs penetration. For these reasons, it is likely that $\mathrm{ZnO}$ NPs will be less likely to result in the selection of resistant bacteria, compared to antibiotics.

However, as a negative aspect, precisely because it involves many mechanisms of antimicrobial activity, it is 
difficult to elucidate all the ways in which $\mathrm{ZnO}$ NPs act on bacteria and fungi. According to the literature review on this topic, it is suggested that ROS production may be responsible for most of the toxicity. However, it is important to emphasise that studies have shown new mechanisms, as demonstrated by Kadiyala et $\mathrm{al}^{40}$ and Tiwari et al. ${ }^{23}$

\section{The Influence Of The Physicochemical Parameters Of ZnO NPs On Their Antimicrobial Activity}

This section covers the structural parameters that may influence the antimicrobial activity of ZnO NPs, focussing on the relationship between the morphology and size of nanoparticles with antimicrobial activity. The control of these parameters is important because the antimicrobial activity of ZnO NPs depends on their intrinsic physicochemical properties. Thus, the toxicity of $\mathrm{ZnO}$ NPs can be altered depending on their morphology and size. Based on these properties, some studies have assessed the impact of the morphology and size of $\mathrm{ZnO}$ NPs on their antimicrobial activities. $^{57,58}$ The morphology control of the ZnO NPs is one of the most important factors for their production; therefore, the reaction parameters should be standardised to ensure the shape and size of the product. ${ }^{50}$

Stanković et $\mathrm{al}^{58}$ studied the influence of $\mathrm{ZnO}$ NPs shape when synthesised by the hydrothermal method using different types of stabilising agents on the antibacterial activity of $\mathrm{ZnO}$ NPs against $E$. coli and $S$. aureus. The shape of the particles was investigated by field emission scanning electron microscopy FE SEM that showed hexagonal prisms $1 \mathrm{~nm}$ in length and $100 \mathrm{~nm}$ in diameter, ellipses with a length of 500-600 nm and a diameter of $100 \mathrm{~nm}$ and spherical particles with diameters around 30 nm. ZnO crystal growth depends on the type of the stabilising agent used in the synthesis. Better antibacterial activity was observed with spherical particles synthesised with polyvinyl alcohol (PVA), which presented a larger surface area and smaller size of $30 \mathrm{~m}^{2} \cdot \mathrm{g}^{-1}$ and $25.70 \mathrm{~nm}$, respectively. In addition, they observed different morphologies for powders prepared with polyvinyl pyrrolidone (PVP) and poly (L-glutamic acid; PGA) presenting greater than $100 \%$ differences in surface area. This feature led to different antibacterial activity in $S$. aureus and $E$. coli. $\mathrm{ZnO}$ powers exhibited almost the same level of antibacterial activity for $E$. coli, while in the case of $S$. aureus, the functional dependence was more strongly related to the value of the surface area measurements. This occurred because $E$. coli cells are more elongated than $S$. aureus cells and they come into contact with a larger number of spherical particles.

Another study conducted by Telebian et $\mathrm{al}^{57}$ synthesised ZnO NPs by the same method of Stanković et al. However, they used other solvents that resulted in different morphologies, ie, 1-hexanol, ethylene glycol and water formed rod-, flower- and spherical morphologies, respectively. Antimicrobial activity was assessed against $S$. aureus and $E$. coli by the colony count method. The bacteria were exposed to samples for $20 \mathrm{mins}$, aiming to evaluate the bactericidal effect under dark and UV light conditions. The results showed that $\mathrm{ZnO}$ nanoflowers had better photocatalytic activity than $\mathrm{ZnO}$ nanorods and nanospheres. Inactivation under UV light and dark conditions increased in the following order: flower-like $>$ spheres $>$ rods.

Pasquet et $\mathrm{al}^{26}$ evaluated the antimicrobial activity of $\mathrm{ZnO}$ NPs in C. albicans, A. brasiliensis, E. coli, P. aeruginosa and $S$. aureus. The challenge test was used in this study to assess the relationship between antimicrobial activity and the structural parameters of $\mathrm{ZnO}$ NPs. Three samples of $\mathrm{ZnO}$ NPs were characterised in terms of crystal size, surface area, porosity and aggregated particles in aqueous medium and in MullerHinton broth. The antimicrobial activity was evaluated by disc diffusion and MIC measurements with the NPs for each microorganism tested. The results showed that the best activity was observed for smaller $\mathrm{ZnO}$ crystals and the antimicrobial activity was dependent on the surface area. The photocatalytic effect was more dependent on the crystallinity than the specific area. The size of the agglomerates was not a relevant parameter, because smaller sizes were obtained and resulted in lower activities against the strains tested. However, the formation of agglomerates should be avoided, in order to minimise sedimentation and to maintain the homogeneity of the suspension. Thus, these authors concluded that the most important parameters to explain antimicrobial activity are a small crystal size and high porosity with large pores.

Raghupathi et al ${ }^{12}$ studied the effect of particle size of $\mathrm{ZnO}$ in terms of antibacterial activity. The results showed that the viability of the cell significantly decreased with decreasing particle size (from $212 \mathrm{~nm}$ to $12 \mathrm{~nm}$ ). When the particle size was larger than $100 \mathrm{~nm}$, the inhibition of methicillin-sensitive $S$. aureus was incomplete. In this case, $\mathrm{ZnO}$ NPs had a bacteriostatic function. The particles smaller than $12 \mathrm{~nm}$ inhibited not only growth but also killed $S$. aureus. The results of confocal microscopy showed that the treatment of bacteria with small-sized 
NPs led to an increase in cell death, probably due to rupture of the bacterial cell wall.

Padmavathy and Vijayaraghavan ${ }^{2}$ studied the antibacterial activity of $\mathrm{ZnO}$ NPs synthesised by two routes that resulted in different particle sizes; therefore, these researchers correlated the influence of NPs size with antibacterial activity. Disk diffusion assays showed that the inhibition zone was increased with smaller sized NPs, which may be related to the ability of these particles to rupture the bacterial membrane. The MIC and $\mathrm{MBC}$ assays were performed using E. coli. At concentrations below $1 \mathrm{mM}$, no significant antibacterial activity was observed in any sample, with $1 \mathrm{mM} \mathrm{ZnO}$ NPs, the activity was bacteriostatic, and concentrations of 5-100 mM were bactericidal. The bactericidal activity found at high and low concentrations was better for a suspension of $12 \mathrm{~nm}$ $\mathrm{ZnO}$ than for $45 \mathrm{~nm}$ and $2 \mu \mathrm{m} \mathrm{NPs}{ }^{2}$

A study conducted by Dutta et $\mathrm{al}^{59}$ aimed to evaluate the changes in oxygen vacancies and the effect of $\mathrm{ZnO}$ NPs size with antibacterial activity. The results show that one of the major factors responsible for regulating the mechanism of toxicity is the difference in oxygen vacancies, with modification of $\mathrm{ZnO}$ properties, as well as particle size, since smaller particles have s larger surface area in relation to volume and can penetrate into the bacterial cell. Furthermore, the increase in oxygen vacancies was responsible for positively loading $\mathrm{ZnO}$ NPs, which enabled interactions with the bacterial cell wall, which has a negative charge.

Shinde et al $^{50}$ studied the antibacterial activity of $\mathrm{ZnO}$ microspheres (ZnO-MS) against $S$. aureus and E. coli. The MIC was found at a concentration of $5 \mathrm{mg} / \mathrm{L}$ for both bacteria. As the concentration increased, complete inhibition was achieved at $75 \mathrm{mg} / \mathrm{mL}$. The ZnO-MS with a smaller size $(20.20 \mathrm{~nm})$ had better antibacterial activity. Jones et al $^{60}$ bought $\mathrm{ZnO}$ NPs in various sizes and performed MIC assays. For ZnO NPs with a smaller size (8 $\mathrm{nm})$, the MIC was $80 \mu \mathrm{g} / \mathrm{mL}$ for $S$. aureus in MullerHilton medium, while that for larger NPs $(50-70 \mathrm{~nm})$ was calculated to be $1.2 \mathrm{mg} / \mathrm{mL}$. Lallo da Silva et al ${ }^{43}$ produced $\mathrm{ZnO}$ NPs with a size of $5 \mathrm{~nm}$ by the sol-gel method; the size of these NPs was increased (21-38 $\mathrm{nm}$ ) with heat treatment. Antibacterial assays were performed to calculate the MIC (Muller-Hilton medium) and MBC against $S$. aureus and $E$. coli. The results showed that the smaller NPs had better antibacterial activity. The MIC (S. aureus) for to the smaller NPs was $78 \mu \mathrm{g} / \mathrm{mL}$. The size influenced the mechanism of action because the
$5 \mathrm{~nm}$ NPs had bactericidal activity and the large NPs had bacteriostatic activity.

Based on these findings, it was possible to observe that there was excellent agreement in the MIC values for $S$. aureus between studies. Lallo da Silva et $\mathrm{al}^{43}$ produced $\mathrm{ZnO}$ NPs with varied sizes (5 nm and 21-38 $\mathrm{nm})$. When we compared the same sizes with the same bacteria and medium used to perform the MIC assay, the same MIC values were found. For example, the particles synthesised by Arakha et al $^{1}$ with a size of $39 \mathrm{~nm}$ and the $\mathrm{ZnO}$ NPs produced by Lallo da Silva et al $(38.25$ $\mathrm{nm}$ ) both had an MIC value of $0.1041 \mathrm{mg} / \mathrm{mL}$. It was also possible to correlate the antibacterial activity of the $\mathrm{ZnO}$ NPs synthesised by Lallo da Silva et $\mathrm{al}^{43}$ with the data presented by Sharma et al. ${ }^{61}$ The ZnO NPs synthesised by Sharma et $\mathrm{al}^{61}$ had a size of $20 \mathrm{~nm}$, while the $\mathrm{ZnO}$ NPs produced by Lallo da Silva et al had a size of $21 \mathrm{~nm}$. The MIC value obtained for $S$. aureus in both cases was $0.31 \mathrm{mg} / \mathrm{mL}$. Comparing the $5 \mathrm{~nm} \mathrm{ZnO} \mathrm{NPs}$ synthesised by Lallo da Silva et $\mathrm{al}^{43}$ with the $8 \mathrm{~nm} \mathrm{ZnO}$ NPs used in the experiments performed by Jones et al, we can observe almost the same MIC for $S$. aureus (around $80 \mu \mathrm{g} / \mathrm{mL}$ ). These findings show once again the importance of $\mathrm{ZnO} \mathrm{NP}$ size on their antibacterial activity.

A study recently conducted by Zhang et $\mathrm{al}^{62}$ on hexagonal faceted $\mathrm{ZnO}$ quantum dots (Qdots) showed that the photocatalytic activity could be explained in three ways. These results could be also applied to the antimicrobial properties. Because $\mathrm{ZnO}$ Qdots are very small nanoparticles, they have a high specific surface area, which enables more contact with the microorganism surface. Another reason is related to the hexagonal faceted morphology. Due to its unsaturated oxygen coordination and positive charge, the (001) face is able to adsorb oxygen molecules and $\mathrm{OH}^{-}$ions. This results in a higher rate of $\mathrm{H}_{2} \mathrm{O}_{2}$ and $\mathrm{OH} \bullet$ radical production, and hence increased antimicrobial activity.

Table 1 provides a summary of the different studies used in this review and the main conclusions. As we can see, the most relevant parameter for excellent activity was the small size of the NPs. It was found that $\mathrm{ZnO}$ NPs with a smaller size are found at a higher concentration in the blood than larger ones (19 and $>100$ $\mathrm{nm}){ }^{63}$ In the same way, the better activity of smaller sized NPs may be attributed the need for more smaller particles to cover the bacterial colony, which results in the generation of higher concentrations of ROS released 


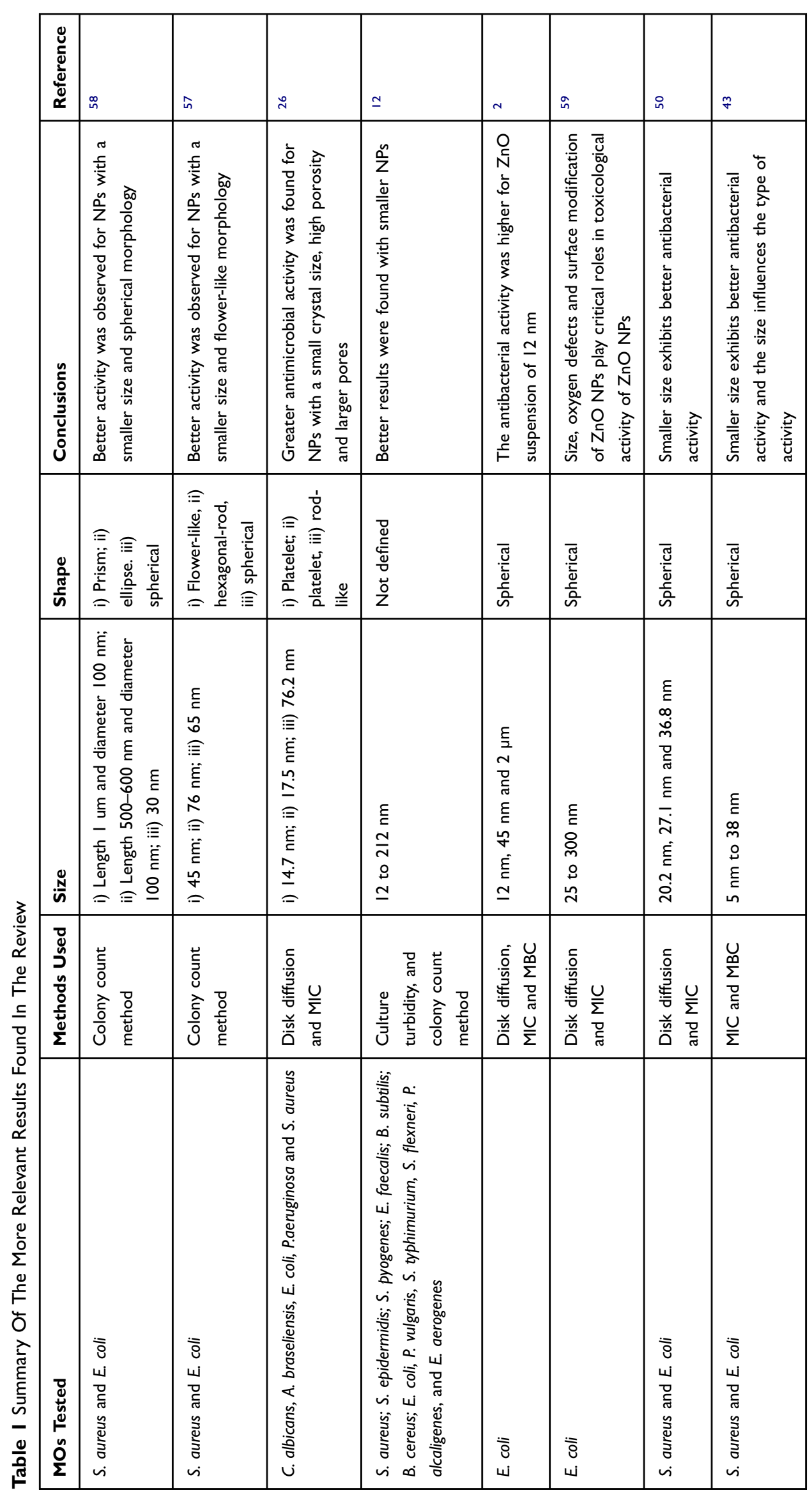


on the surface of the colony, promoting bacterial death more efficiently. ${ }^{2}$ In addition, smaller NPs can penetrate the bacterial membrane more easily due to the high interfacial area. $^{17}$ In addition, $\mathrm{ZnO}$ NPs dissolution into $\mathrm{Zn}^{2+}$ ions has been reported as being a size-dependent phenomenon ${ }^{44,64,65}$ and as previously mentioned, $\mathrm{Zn}^{2+}$ ions may be responsible for the antimicrobial activity of ZnO NPs. In summary, although NP morphology is a very important parameter, all the antimicrobial mechanisms of ZnO NPs are size-dependent. Thus, ZnO NPs with a very small size may result in optimised antimicrobial activity.

\section{Zinc Oxide Surface Modification And Doping: Relationship With Antimicrobial Activity}

Although the uses of ZnO NPs are diverse, their instability in water limits their biological applications, considering that biomolecules such as DNA, proteins and peptides are present in aqueous media. Therefore, surface modifications to $\mathrm{ZnO}$ NPs are performed in order to improve the dispersion of biomolecules. For these reasons, different strategies have been explored in an attempt to change the $\mathrm{ZnO}$ NPs surface to make them stable in water. ${ }^{66}$

Surface modifications enhanced the dispersion of $\mathrm{ZnO}$ NPs and resulted in less aggregation. This finding was demonstrated by Aditya et al, ${ }^{67}$ who dispersed $\mathrm{ZnO}$ NPs in an ionic liquid. This enhanced the bactericidal efficacy against $S$. epidermidis because $\mathrm{ZnO}$ NPs in ionic liquids showed elevated production of ROS.

In addition to surface modifications used to improve stability as mentioned earlier, it is possible to design systems in which the surface of $\mathrm{ZnO}$ NPs is altered in order to optimise their antimicrobial activity. For example, this can be done using organosilanes. Organosilanes can be formed by different organic functional groups and are precursors of corresponding organosilanols or organosilsesquioxanes. They are inorganic-organic hybrid materials that can be applied to different substances to modify their surface by attaching oxides by silyation. ${ }^{68}$ Thus, for the stabilisation of $\mathrm{ZnO}$ NPs, researchers have modified their surface with organosilanes, because these molecules bind covalently to the hydroxylated surface of NPs, making them stable in water by creating a barrier that protects the NPs in the nucleus and allows the dispersion of NPs in water. ${ }^{69,70}$
The surface topography of a material can change bacterial behaviour. This occurs because surface properties affect cellular adhesion and influence cellular metabolism. ${ }^{71} \mathrm{~A}$ study conducted by Jana et $\mathrm{al}^{72}$ showed that $\alpha \mathrm{Fe}_{2} \mathrm{O}_{3}-\mathrm{ZnO}$ nanocomposites in the nanoscale and microscale had differences in terms of the roughness of the surface morphology. Thus, it was concluded that surface roughness is very important for antibacterial activity. The surface properties of nanomaterials alter interactions with the cell and can interfere with the antimicrobial effect of $\mathrm{ZnO} N \mathrm{NPs}^{49}$

Doping of metal oxides is one strategy to improve their photocatalytic properties and can result in changes to the surface area due to the introduction of dopant ions. Thus, the presence of impurities in semiconductor NPs can lead to dramatic changes in their structural, electrical and optical properties. The introduction of dopants during the nanostructure formation process will cause new crystal growth conditions, inducing drastic changes in internal defects and morphology. ${ }^{73-75}$ In these defects, enhanced oxygen vacancy favours photocatalytic reactions, and therefore a higher amount of ROS is produced. ${ }^{76,77}$

The presence of dopant ions in ZnO NPs has been used in some studies to assess their relationships with the antimicrobial activity of ZnO NPs. ${ }^{61,78}$ The presence of these dopant ions can change the size of $\mathrm{ZnO} N \mathrm{NPs}^{79}$ This characteristic is important for the antimicrobial effect of NPs. In addition, higher ROS concentrations result in greater antimicrobial activity by $\mathrm{ZnO}$ NPs; ROS generation is a major mechanism responsible for $\mathrm{ZnO}$ NPs antimicrobial activity. The abovementioned toxicity mechanisms, such as the production of oxygen radicals, $\mathrm{Zn}^{2+}$ ions and the interaction of $\mathrm{ZnO}$ NPs with the cell membrane, are affected by surface coatings, ${ }^{80}$ and these surface characteristics may help in interactions between NPs and the cell wall of bacteria and fungi. ${ }^{81}$

Based on the relevant information presented in this section, the next items will be discussed in order to show the influence of antimicrobial activity obtained with the introduction of dopants or surface modifiers (with a focus on organosilanes) in ZnO NPs. The discussion about these parameters is very important because ZnO NPs structural changes result in new properties that can enhance the antimicrobial activity of $\mathrm{ZnO}$ NPs. Understanding how doping and surface modifications alter the properties of $\mathrm{ZnO}$ NPs is already a challenge. However, applying these findings to antimicrobial activity may be an excellent alternative to achieve $\mathrm{ZnO}$ NPs-based systems with excellent antimicrobial properties. 


\section{Doped ZnO NPs}

Sharma et $\mathrm{al}^{61}$ studied the antimicrobial activities of doped $\mathrm{ZnO}$ NPs against fungi, Gram-positive and Gram-negative bacteria using standard isolates ( $\mathrm{S}$ ) and clinical isolates (C), by the microdilution method. The researchers used pure doped $\mathrm{ZnO}$ NPs with $1 \%$ and $10 \% \mathrm{Fe}, \mathrm{Mn}, \mathrm{Cu}$ and $\mathrm{Co}$ and correlated the synergistic effect of NPs with antimicrobial agents such as ciprofloxacin (Cip), ampicillin (Amp), fluconazole (Flu) and amphotericin B (Amp B). The results showed that there were significant differences in the MIC values for undoped and doped NPs. Better antimicrobial activity was obtained with $10 \%$ dopant than for $1 \%$ doped and undoped NPs. Synergistic interactions were observed with Cip and Amp for NPs with 10\% dopant. For fungi, only an additive effect was found with Flu and Amp B. The presence of dopants can accelerate ROS formation due to the synergistic effect of $\mathrm{Mn}, \mathrm{Cu}, \mathrm{Co}$ and $\mathrm{Fe}$, which improve the photocatalytic activity of $\mathrm{ZnO}$ NPs.

Based on this improvement in the activity of ciprofloxacin when associated with $\mathrm{ZnO}$ NPs, some researchers assumed that $\mathrm{ZnO}$ NPs may interfere with the pumping activity of NorA protein in S. aureus. NorA protein mediates hydrophilic fluoroquinolone efflux to the cell, conferring resistance to the microorganism. Recent reports have suggested that metallic oxide NPs are able to induce faster transfer of electrons to the active sites of enzymes, so ZnO NPs could interfere with the pumping activity of this protein (overexpression of the protein is related to cases of microbial resistance to the action of fluoroquinolones in S. aureus and E. coli) ${ }^{61,82-84}$ Another explication can be attributed to $\mathrm{ZnO}$ NPs relationship with the increased absorption of antibiotics in $S$. aureus cells, which is mediated by the Omf protein (responsible for the permeation of quinolones through the cell membrane). ${ }^{61,82,85}$

Some antibiotics are able to form complexes with metal ions, such as $\mathrm{Co}, \mathrm{Ni}$ and $\mathrm{Cu}$, as shown by Patel et al, who demonstrated the ability of ciprofloxacin to form a complex with chelating agents. In this way, it is possible that the fluorine atom reacts with the $\mathrm{Zn}$ atom, stabilising the combination of Cip-ZnO. ${ }^{86}$

Ravichandran et $\mathrm{al}^{87}$ doped $\mathrm{ZnO}$ NPs with $\mathrm{Cu}$ and graphene. No change in antibacterial activity was observed with $\mathrm{ZnO}: \mathrm{Cu}$. It is important to highlight that the concentration of $\mathrm{Cu}$ (less than 1\%) was less than that in the studies conducted by Sharma et al. ${ }^{61}$ Thus, differences in the concentration of a dopant can result in different activities.
Ravichandran et $\mathrm{al}^{87}$ found enhanced antibacterial properties with $\mathrm{ZnO}: \mathrm{Cu}$ :graphene. The researchers attributed the improved antibacterial activity due to the smaller crystallite size. This was explained because, with a smaller size, the number of $\mathrm{ZnO}$ NPs per volume increases, as well as the surface area; this results in greater generation of $\mathrm{H}_{2} \mathrm{O}_{2}$.

Some studies have evaluated the effect of silver $(\mathrm{Ag})$ doped $\mathrm{ZnO}$ NPs. ${ }^{88,89}$ Bechambi et al showed that the antibacterial activity of Ag-doped $\mathrm{ZnO}$ NPs was better than undoped ones. The authors attributed these increases in antibacterial activity to the presence of $\mathrm{Ag}$ that can interact with bacterial cells and adhere to bacterial cell walls. Thus, Ag doping affects the adhesion properties of $\mathrm{ZnO}$ and influences its inactivation behaviour. In contrast to this study, Kumar et $\mathrm{al}^{88}$ observed that undoped $\mathrm{ZnO}$ NPs had better antibacterial activity than Ag-doped $\mathrm{ZnO}$ NPs against $S$. aureus and E. coli. They discussed this result with the formation of $\mathrm{Ag}_{2} \mathrm{O}$ and subsequent loss of oxygen vacancies obtained with doped $\mathrm{Ag} \mathrm{ZnO}$ compared to undoped $\mathrm{ZnO}$, which negatively affected the antibacterial properties.

Research conducted by Rekha et $\mathrm{al}^{78}$ assessed the antibacterial activity of ZnO NPs doped with Mn, using the disk diffusion method. The X-ray diffraction results indicated that $\mathrm{Mn}^{2+}$ ions replaced $\mathrm{Zn}^{2+}$ ions with no change in the wurtzite structure. Mn-doped ZnO NPs exhibited better antibacterial activity than undoped $\mathrm{ZnO}$ NPs against Gram-positive and Gram-negative bacteria.

Sehmi et $\mathrm{al}^{90}$ evaluated the bactericidal activity of $\mathrm{ZnO}$, $\mathrm{Mg}$-doped $\mathrm{ZnO}$, and $\mathrm{MgO}$ NPs in clinical isolates. These materials had promising antibacterial activity against $S$. aureus and E. coli. However, Mg-doped $\mathrm{ZnO}$ did not show strong antibacterial activity.

Guo and co-workers ${ }^{31}$ studied the antimicrobial activity of Ta-doped $\mathrm{ZnO}$ NPs and showed that the MIC was influenced by the $\mathrm{Ta}^{+5}$ ions incorporated into $\mathrm{ZnO}$; this had a strong influence on the antibacterial effect of $\mathrm{ZnO}$ NPs against P. aeruginosa, E. coli, S. aureus and B. subtilis. Possible mechanisms of antibacterial activity were proposed since Ta-doped NPs showed more effective bactericidal efficacy than pure $\mathrm{ZnO}$. This effect was attributed to the synergistic effect of enhanced surface bioactivity and increased electrostatic force due to the incorporation of $\mathrm{Ta}^{+}$.

Hammed et $\mathrm{al}^{91}$ studied the antibacterial activity of undoped $\mathrm{ZnO}$ NPs and $\mathrm{ZnO}$ NPs doped with neodymium (Nd) against enzymes called extended-spectrum beta-lactamases (ESBL), produced by E. coli and Klebsiella pneumoniae. ESBL confer resistance to many antibiotics such 
as penicillin and cephalosporin. The results showed that $\mathrm{Nd}$-doped ZnO NPs presented higher antibacterial activity than pure $\mathrm{ZnO}$ NPs.

Bomila et $\mathrm{al}^{76}$ synthesised dual doped ZnO NPs with rare earth elements such as cerium (Ce), lanthanum (La) and gadolinium (Gd). There was an increase in ROS achieved by $\mathrm{Ce}-\mathrm{La}$ dual-doped $\mathrm{ZnO}$ NPs compared to NOP doped with the other ions. However, the particle size of this sample was smaller than the other doped $\mathrm{ZnO}$ NPs. Additionally, Ce-La ZnO NPs had more lattice defects and higher photocatalytic efficiency. Thus, the researchers attributed these characteristics to the enhancement of antibacterial activity.

$\mathrm{ZnO}$ NPs were dual doped with $\mathrm{Sn}$ and $\mathrm{Cu}$ by Vignesh et al. $^{92}$ The results showed that dual-doped $\mathrm{ZnO}$ NPs induced larger zones of inhibition in antibacterial assays than pure $\mathrm{ZnO}$ and $\mathrm{Sn}: \mathrm{ZnO}$ and $\mathrm{Cu}: \mathrm{ZnO}$. The authors suggested that, although the antibacterial activity was attributed the higher amount of ROS produced by dual doped ZnO NPs and the deposition of NPs on the surface of the bacteria, a decrease in crystallite size was also one of the reasons for the enhanced antibacterial activity.

In this section, we showed that doping ZnO NPs may be one way to enhance antibacterial properties due to increases in oxygen vacancies and ROS production. However, not all doping strategies resulted in better activity, even when using the same dopant. This shows that the improvement of activity does not depend solely on the dopant but also on the structural characteristics of $\mathrm{ZnO}$ NPs. Therefore, it is important to control the reaction in order to produce doped nanoparticles with large quantities of oxygen vacancies and with small sizes. Doped ZnO NPs with small sizes showed the best antibacterial activity.

Surface Modified ZnO NPs: Focus On Organosilanes Farouk et $\mathrm{al}^{93}$ studied $\mathrm{ZnO}$ containing 3-glycidyloxypropyltrimethoxysilane (GPTMS) as an antibacterial agent for textile industries. The sol-gel method proposed by Spanhel and Anderson, ${ }^{94}$ with some modifications, was used to produce $\mathrm{ZnO}$ NPs and the disc diffusion assay provided information about antibacterial activity. The zone of inhibition was observed, and its diameter was used to measure the antibacterial activity of $\mathrm{ZnO}$ NPs with GPTMS. The test was carried out against $M$. luteus and E. coli. The results showed that cotton samples containing $\mathrm{ZnO}$ modified with GPTMS after 5 hrs of treatment had $98.8 \%$ less contamination with $E$. coli and $97.3 \%$ less contamination with M. luteus. The polymer alone provided no inhibition, so it can be concluded that the modified $\mathrm{ZnO}$ NPs have promising antibacterial activity in textile materials.

Lallo da Silva et $\mathrm{al}^{43}$ studied $\mathrm{ZnO}$ NPs modified by GPTMS to investigate the antibacterial activity against $E$. coli and S. aureus. The $\mathrm{ZnO}$ NPs could be dispersed in water and the NPs presented excellent antibacterial activity at low concentrations. For example, NPs at $0.1367 \mathrm{mg} /$ $\mathrm{mL}$ had bactericidal activity against $S$. aureus.

Li et al ${ }^{95}$ modified $\mathrm{ZnO}$ NPs with aminoethylaminopropyl-trimethoxy silane (KH550) and $\gamma$-glycidoxypropyl-trimethoxysilane (here, referred to as KH560). Then, modified $\mathrm{ZnO}$ were coupled with polyethylene (HDPE) composite films for the evaluation of antibacterial activity. The results showed that HDPE did not present any activity against $S$. aureus and E. coli. On the other hand, surface modification of $\mathrm{ZnO}$ with HDPE improved the antibacterial activity compared to unmodified ZnO-HDPE. KH560-modified $\mathrm{ZnO}-\mathrm{HDPE}$ had better activity than KH550-modified ZnO-HDPE.

Soumya et al $^{96}$ modified ZnO NPs with 3-(aminopropyl) trimethoxy silane and then provided them with poly(methyl methacrylate) (PMMA) polymeric coatings for application to cotton textiles. The results showed that the textiles were resistant to the growth of the fungi Aspergillus flavus and Aspergillus niger, and the coating also made the textile less prone to water absorption.

Kamonkhantikul et $\mathrm{al}^{97}$ incorporated PMMA with $\mathrm{ZnO}$ NPs modified with methacryloxypropyltrimethoxysilane. The silane-ZnO NPs had greater antifungal activity against C. albicans than unmodified NPs. The difference in the antifungal activity may have been due to the better distribution of silane-ZnO NPs in PMMA compared to unmodified NPs. The higher surface energy present in unmodified NPs may have resulted in a low surface-to-volume ratio and consequently poor dispersion. Hydroxyl groups in the $\mathrm{ZnO}$ NPs react with silane groups, which increases the distance between $\mathrm{ZnO}$ NPs. In this way, better distribution of $\mathrm{ZnO}$ NPs in PMMA was expected. This can maintain particle size; moreover, with a high surface-to-volume ratio, there is increased contact between $\mathrm{ZnO}$ NPs and $C$. albicans, which enhanced the antifungal effect.

Leung et $\mathrm{al}^{49}$ evaluated the antibacterial activity of various silane-based surface modified $\mathrm{ZnO}$ NPs in a light environment using the Gram-positive bacteria $B$. atrophaeus and E. faecium and the Gram-negative bacterium E. coli. According to the results, different surface modifications of $\mathrm{ZnO}$ NPs can affect the release of 
$\mathrm{Zn}^{2}+$ and the production of ROS and thereby affect antibacterial activity. Bacteria died with or without surface modifications. The increase in $\mathrm{Zn}^{2}+$ release was not related to increased activity, but lower $\mathrm{Zn}^{2+}$ concentrations were associated with better antibacterial properties. Silane surface modifiers containing amino groups caused changes in the cell structure, ie, deforming it, which indicated a change in membrane permeability and suggested antibacterial activity.

Cepin et $\mathrm{al}^{98}$ synthesised $\mathrm{ZnO}$ nanocrystals and functionalised them with amino and ionic-liquid silane anchoring groups to obtain a hybrid material. Two ionic liquids containing silanes were selected, which contained in their chemical structure one, two or three amino groups. These amino groups have attractive antimicrobial properties, especially those containing quaternary amine since the positive charges are attracted to the negative charges of the bacterial membrane. Studies were performed in relation to the MIC of $\mathrm{ZnO}$ nanocrystals without modification. For unmodified $\mathrm{ZnO}$, the results showed that a concentration of $0.125 \mathrm{~g} / \mathrm{L}$ inhibited $50 \%$ of the bacterial growth and a concentration of $0.25 \mathrm{~g} / \mathrm{L}$ completely inhibited the growth of $S$. aureus and E. coli. The authors concluded that $\mathrm{ZnO}$ nanocrystals with modified surfaces containing ionic liquids and amino groups have excellent antimicrobial activity, inactivating $100 \%$ of the bacteria at low concentrations. However, not all changes decreased the MIC values compared to pristine $\mathrm{ZnO}$.

Milović et al ${ }^{99}$ sought to elucidate issues of the antimicrobial effect and the practical use of antimicrobial coatings. The bacterial resistance developed against polycationic coatings was tested using $E$. coli and $S$. aureus. The results showed notable bactericidal action of amino-glass slides obtained by chemical derivatisation with N-hexyl, methylpolyethylenimine, resulting from the rupture of bacterial cell membranes. Additionally, the rare bacterial survivors did not develop resistance. The authors suggested that they probably survived by avoiding contact with the immobilised polycationic coating.

A study conducted by Arakha et $\mathrm{al}^{1}$ showed modifications to $\mathrm{ZnO}$ NPs resulting in two types of surface with opposite potential. A correlation was established between the zeta potential of bacterial cells, the surface charge of the NPs and the antibacterial effect. The results showed that positively charged particles showed higher antimicrobial activity against Gram-positive and Gram-negative bacteria in relation to negatively charged
NPs, considering that a repulsive force is established with the bacterial surface that also has negative charges.

Ozkan et al $^{100}$ studied the bactericidal activity of polydimethylsiloxane (PDMS) coated with crystal violet, which possess antibacterial activity, in the presence of $\mathrm{ZnO}$ NPs. This activity was compared with a polymer containing crystal violet without $\mathrm{ZnO}$ NPs and only $\mathrm{ZnO}$ NPs. The analysis of antibacterial activity was performed using E. coli and $S$. aureus. The results showed that the developed material had better antibacterial activity than pure $\mathrm{ZnO} .^{100}$

In addition to silanes, $\mathrm{ZnO}$ NPs are associated with other compounds to achieve optimised antibacterial activity. In studies performed by Sehmi et al, ${ }^{90}$ it was demonstrated that oleate-capped $\mathrm{ZnO}$ NPs combined with crystal violet were biocompatible and significantly reduced the numbers of $S$. aureus, possibly due to the oleate ligand itself. Additionally, $\mathrm{ZnO}$ capped with di(octyl)phosphinic acid (DOPA) showed excellent antibacterial activity against E. coli without a photosensitiser or white-light activation. However, regarding antibacterial activity against strains of methicillin-resistant $S$. aureus (MRSA), better antibacterial activity was obtained with $\mathrm{ZnO}$ NPs prepared with crystal violet and DOPA. The smaller size of the ZnO-DOPA NPs $(\sim 2-4 \mathrm{~nm})$ compared to that of $\mathrm{ZnO}$ _OA NPs $(\sim 18 \mathrm{~nm})$ resulted in better antibacterial activity.

Although there are many methods for modifying the surface of $\mathrm{ZnO}$ NPs, the use of organosilanes has become one of the most widely used methods. The major advantage of using silanes is their rapid covalent bond formation, which results in a thin layer on the surface of the $\mathrm{ZnO}$. This covalent bonding is responsible for stabilising the monolayer, making further modification easy without compromising the integrity of the surface film. ${ }^{101}$

In a study conducted by Soumya et al, ${ }^{96}$ it was observed that silane-modified ZnO NPs had a very narrow size distribution with an average particle size of $220 \mathrm{~nm}$. In contrast, without modification, the size distribution was bimodal, and in this case, the particles were in the range of 255-970 $\mathrm{nm}$. The wide size distribution clearly indicated that, in the absence of silane, $\mathrm{ZnO}$ nanoaggregates were obtained.

In summary, this section has shown that different silanes can be used to modify $\mathrm{ZnO}$ NPs. Although there are many strategies for performing $\mathrm{ZnO}$ surface modification, the use of silanes has many advantages. In 
addition to the rapid reaction, there are many silanes on the market that allow nanoparticles to be dispersed in hydrophilic or hydrophobic media, improving their stabilisation. However, the main advantage of using these silanes is the size control of the formed NPs. For example, GPTMS-modified ZnO NPs showed greater resistance to growth when subjected to high temperatures compared to unmodified NPs. ${ }^{43}$ This control of nanoparticle growth coupled with a better size distribution results in a system with better antimicrobial properties, enabling the formation of nanoparticles with optimised antimicrobial properties, since obtaining small NPs is one of the requirements for improving antimicrobial activity.

\section{Conclusion}

The lack of a standard in relation to the microbial strains used in these studies and the methodologies for microbiological testing are sources of uncertainty. However, in this review, it was possible to see that the most important mechanism to explain the antimicrobial activity of $\mathrm{ZnO}$ NPs is ROS production.

Some researchers have shown that the different physical and chemical parameters can change the antimicrobial activity of $\mathrm{ZnO}$ NPs; the most relevant parameter found in our review regarding antimicrobial activity was the size of ZnO NPs. The importance of size as the most relevant parameter is supported by the same MIC values found in studies performed by different researchers using nanoparticles of the same size. In addition, when studies compared nanoparticles with different morphologies, generally those that were more toxic to microorganisms were also smaller.

The use of dopants can increase the activity of $\mathrm{ZnO}$ NPs. As the proportion of dopants increases, NPs tend to decrease in size. In addition, in general, larger amounts of ROS are produced, which results in better activity. Surface modifications of $\mathrm{ZnO} \mathrm{NPs}$, in general, lead to improved antimicrobial activity, reducing the MIC of these NPs against the tested microorganisms. This happens due to the improved size distribution and growth resistance of $\mathrm{ZnO}$ NPs. These findings once again support the need for nanoparticle size control to achieve optimal antimicrobial activity.

The limitations and future outlook consist of better understanding the antibacterial activity of $\mathrm{ZnO}$ NPs, which is a challenge because studies continually reveal new mechanisms, which shows that not all existing mechanisms are understood and there is a need to better explore this area. The lack of a standard in relation to the microbial strains used in these studies and the methodologies for microbiological tests has led to conflicting results. There are many studies on ROS toxicity, but only the intracellular inhibitory mechanisms and protein synthesis, gene expression and metabolism of bacterial cells. Thus, as future perspectives, it is important that further research be conducted in this regard.

\section{Acknowledgments}

The authors thank São Paulo Research Foundation (FAPESP), Coordination for the Improvement of Higher Education (CAPES) - Finance Code 001. We also thank the Scientific Support and Development Program of School of Pharmaceutical Sciences (PADCUNESP).

\section{Disclosure}

The authors have declared no conflict of interest in this work.

\section{References}

1. Arakha M, Saleem M, Mallick BC, Jha S. The effects of interfacial potential on antimicrobial propensity of $\mathrm{ZnO}$ nanoparticle. Sci Rep. 2015;5. doi:10.1038/srep09578

2. Padmavathy N, Vijayaraghavan R. Enhanced bioactivity of $\mathrm{ZnO}$ nanoparticles-an antimicrobial study. Sci Technol Adv Mater. 2016;9:035004.

3. Derewacz DK, Goodwin CR, McNees CR, McLean JA, Bachmann BO. Antimicrobial drug resistance affects broad changes in metabolomic phenotype in addition to secondary metabolism. Proc Natl Acad Sci. 2013;110(6):2336-2341. doi:10.1073/pnas.1218524110

4. von Wintersdorff $\mathrm{CJH}$, Penders J, van Niekerk JM, et al. Dissemination of antimicrobial resistance in microbial ecosystems through horizontal gene transfer. Front Microbiol. 2016;7. doi:10.3389/fmicb.2016.00173

5. Carrillo-Munoz AJ, Giusiano G, Ezkurra PA, Quindós G. Antifungal agents: mode of action in yeast cells. Rev Esp Quimioter. 2006;19 (2):130-139.

6. Landini P, Antoniani D, Burgess JG, Nijland R. Molecular mechanisms of compounds affecting bacterial biofilm formation and dispersal. Appl Microbiol Biotechnol. 2010;86(3):813-823. doi:10.1007/s00253010-2468-8

7. Hooper DC. Mechanisms of action of antimicrobials: focus on fluoroquinolones. Clin Infect Dis. 2001;32(Supplement 1):S9-S15. doi: $10.1086 / 319370$

8. Wang $\mathrm{L}$, Hu C, Shao L. The antimicrobial activity of nanoparticles: present situation and prospects for the future. Int $J$ Nanomedicine. 2017;12:1227. doi:10.2147/IJN.S121956

9. Rai M. Nanobiotecnologia verde: biossínteses de nanopartículas metálicas e suas aplicações como nanoantimicrobianos. Ciência E Cultura. 2013;65 (3):44 48. doi:10.21800/S0009-67252013000300014 
10. Durairaj B, Muthu S, Xavier T. Antimicrobial activity of Aspergillus niger synthesized titanium dioxide nanoparticles. $A d v$ Appl Sci Res. 2015;6:45-48.

11. Firouzabadi FB, Noori M, Edalatpanah Y, Mirhosseini M. ZnO nanoparticle suspensions containing citric acid as antimicrobial to control Listeria monocytogenes, Escherichia coli, Staphylococcus aureus and Bacillus cereus in mango juice. Food Control. 2014;42:310-314. doi:10.1016/j.foodcont.2014.02.012

12. Raghupathi KR, Koodali RT, Manna AC. Size-dependent bacterial growth inhibition and mechanism of antibacterial activity of zinc oxide nanoparticles. Langmuir. 2011;27(7):4020-4028. doi:10.1021/ la104825u

13. Manoharan C, Pavithra G, Dhanapandian S, Dhamodaran P, Shanthi B. Properties of spray pyrolised $\mathrm{ZnO}$ : Sn thin films and their antibacterial activity. Spectrochim Acta Part A. 2015;141:292299. doi:10.1016/j.saa.2015.01.051

14. Liu Y, He L, Mustapha A, Li H, Hu ZQ, Lin M. Antibacterial activities of zinc oxide nanoparticles against Escherichia coli O157: H7. J Appl Microbiol. 2009;107(4):1193-1201. doi:10.1111/j.1365-2672.2009.04 303.x

15. Janaki AC, Sailatha E, Gunasekaran S. Synthesis, characteristics and antimicrobial activity of $\mathrm{ZnO}$ nanoparticles. Spectrochim Acta Part A. 2015;144:17-22. doi:10.1016/j.saa.2015.02.041

16. Pasquet J, Chevalier Y, Couval E, Bouvier D, Bolzinger M-A. Zinc oxide as a new antimicrobial preservative of topical products: interactions with common formulation ingredients. Int J Pharm. 2015;479(1):88-95. doi:10.1016/j.ijpharm.2014.12.031

17. Sirelkhatim A, Mahmud S, Seeni A, et al. Review on zinc oxide nanoparticles: antibacterial activity and toxicity mechanism. NanoMicro Lett. 2015;7(3):219-242. doi:10.1007/s40820-015-0040-x

18. Zheng MJ, Zhang LD, Li GH, Shen WZ. Fabrication and optical properties of large-scale uniform zinc oxide nanowire arrays by one-step electrochemical deposition technique. Chem Phys Lett. 2002;363(1):123-128. doi:10.1016/S0009-2614(02)01106-5

19. Jagadish C, Pearton SJ. Zinc Oxide Bulk, Thin Films and Nanostructures: Processing, Properties, and Applications. Elsevier; 2011.

20. Talam S, Karumuri SR, Gunnam N. Synthesis, characterization, and spectroscopic properties of $\mathrm{ZnO}$ nanoparticles. ISRN Nanotechnol. 2012;2012. doi:10.5402/2012/372505

21. Ahmad M, Zhu J. ZnO based advanced functional nanostructures: synthesis, properties and applications. J Mater Chem. 2011;21 (3):599-614. doi:10.1039/C0JM01645D

22. Rana S, Rawat J, Sorensson MM, Misra RDK. Antimicrobial function of $\mathrm{Nd} \mathrm{3+-doped} \mathrm{anatase} \mathrm{titania-coated} \mathrm{nickel} \mathrm{ferrite} \mathrm{com-}$ posite nanoparticles: a biomaterial system. Acta Biomater. 2006;2 (4):421-432. doi:10.1016/j.actbio.2006.03.005

23. Tiwari V, Mishra N, Gadani K, Solanki PS, Shah N, Tiwari M. Mechanism of anti-bacterial activity of zinc oxide nanoparticle against carbapenem resistant Acinetobacter baumannii. Front Microbiol. 2018;9:1218. doi:10.3389/fmicb.2018.01218

24. Alves MM, Bouchami O, Tavares A, et al. New insights into antibiofilm effect of a nanosized $\mathrm{ZnO}$ coating against the pathogenic methicillin resistant Staphylococcus aureus. ACS Appl Mater Interfaces. 2017;9(34):28157-28167. doi:10.1021/acsami.7b02320

25. Hajipour MJ, Fromm KM, Ashkarran AA, et al. Antibacterial properties of nanoparticles. Trends Biotechnol. 2012;30(10):499511. doi:10.1016/j.tibtech.2012.06.004

26. Pasquet J, Chevalier Y, Couval E, et al. Antimicrobial activity of zinc oxide particles on five micro-organisms of the challenge tests related to their physicochemical properties. Int J Pharm. 2014;460 (1):92-100. doi:10.1016/j.ijpharm.2013.10.031

27. Baek Y-W, An Y-J. Microbial toxicity of metal oxide nanoparticles $(\mathrm{CuO}, \mathrm{NiO}, \mathrm{ZnO}$, and $\mathrm{Sb} 2 \mathrm{O} 3)$ to Escherichia coli, Bacillus subtilis, and Streptococcus aureus. Sci Total Environ. 2011;409 (8):1603-1608. doi:10.1016/j.scitotenv.2011.01.014
28. Shoeb M, Singh BR, Khan JA, et al. ROS-dependent anticandidal activity of zinc oxide nanoparticles synthesized by using egg albumen as a biotemplate. Adv Nat Sci. 2013;4(3):035015.

29. Applerot G, Lellouche J, Perkas N, Nitzan Y, Gedanken A, Banin E. $\mathrm{ZnO}$ nanoparticle-coated surfaces inhibit bacterial biofilm formation and increase antibiotic susceptibility. RSC Adv. 2012;2 (6):2314-2321. doi:10.1039/c2ra00602b

30. Sawai J, Shoji S, Igarashi H, et al. Hydrogen peroxide as an antibacterial factor in zinc oxide powder slurry. J Ferment Bioeng. 1998;86 (5):521-522. doi:10.1016/S0922-338X(98)80165-7

31. Guo B-L, Han P, Guo L-C, et al. The antibacterial activity of Tadoped ZnO nanoparticles. Nanoscale Res Lett. 2015;10(1):1-10. doi:10.1186/1556-276X-10-1

32. Brayner R, Ferrari-Iliou R, Brivois N, Djediat S, Benedetti MF, Fiévet F. Toxicological impact studies based on Escherichia coli bacteria in ultrafine $\mathrm{ZnO}$ nanoparticles colloidal medium. Nano Lett. 2006;6(4):866-870. doi:10.1021/n1052326h

33. Zhang L, Jiang Y, Ding Y, Povey M, York D. Investigation into the antibacterial behaviour of suspensions of $\mathrm{ZnO}$ nanoparticles $(\mathrm{ZnO}$ nanofluids). J Nanopart Res. 2007;9(3):479-489. doi:10.1007/ s11051-006-9150-1

34. Brunner TJ, Wick P, Manser P, et al. In vitro cytotoxicity of oxide nanoparticles: comparison to asbestos, silica, and the effect of particle solubility. Environ Sci Technol. 2006;40(14):4374-4381. doi:10.1021/es052069i

35. Li M, Zhu L, Lin D. Toxicity of ZnO nanoparticles to Escherichia coli: mechanism and the influence of medium components. Environ Sci Technol. 2011;45(5):1977-1983. doi:10.1021/es102624t

36. Seven O, Dindar B, Aydemir S, Metin D, Ozinel MA, Icli S. Solar photocatalytic disinfection of a group of bacteria and fungi aqueous suspensions with $\mathrm{TiO} 2, \mathrm{ZnO}$ and Sahara desert dust. J Photochem Photobiol A. 2004;165(1):103-107. doi:10.1016/j.jphotochem. 2004.03.005

37. Adams LK, Lyon DY, Alvarez PJJ. Comparative eco-toxicity of nanoscale $\mathrm{TiO} 2, \mathrm{SiO} 2$, and $\mathrm{ZnO}$ water suspensions. Water Res. 2006;40(19):3527-3532. doi:10.1016/j.watres.2006.08.004

38. Hirota K, Sugimoto M, Kato M, Tsukagoshi K, Tanigawa T, Sugimoto H. Preparation of zinc oxide ceramics with a sustainable antibacterial activity under dark conditions. Ceram Int. 2010;36 (2):497-506. doi:10.1016/j.ceramint.2009.09.026

39. d'Água RB, Branquinho R, Duarte MP, et al. Efficient coverage of $\mathrm{ZnO}$ nanoparticles on cotton fibres for antibacterial finishing using a rapid and low cost in situ synthesis. New J Chem. 2018;42 (2):1052-1060. doi:10.1039/C7NJ03418K

40. Kadiyala U, Turali-Emre ES, Bahng JH, Kotov NA, VanEpps JS. Unexpected insights into antibacterial activity of zinc oxide nanoparticles against methicillin resistant Staphylococcus aureus (MRSA). Nanoscale. 2018;10(10):4927-4939. doi:10.1039/ c7nr08499d

41. Cho W-S, Duffin R, Howie SEM, et al. Progressive severe lung injury by zinc oxide nanoparticles; the role of $\mathrm{Zn} 2+$ dissolution inside lysosomes. Part Fibre Toxicol. 2011;8(1):27. doi:10.1186/ 1743-8977-8-27

42. Li Y, Zhang W, Niu J, Chen Y. Mechanism of photogenerated reactive oxygen species and correlation with the antibacterial properties of engineered metal-oxide nanoparticles. ACS Nano. 2012;6 (6):5164-5173. doi:10.1021/nn300934k

43. Lallo da Silva B, Caetano BL, Chiari-Andréo BG, Pietro RCLR, Chiavacci LA. Increased antibacterial activity of $\mathrm{ZnO}$ nanoparticles: influence of size and surface modification. Colloids Surf B. 2019;177:440-447. doi:10.1016/j.colsurfb.2019.02.013

44. Heinlaan M, Ivask A, Blinova I, Dubourguier H-C, Kahru A. Toxicity of nanosized and bulk $\mathrm{ZnO}, \mathrm{CuO}$ and $\mathrm{TiO} 2$ to bacteria Vibrio fischeri and crustaceans Daphnia magna and Thamnocephalus platyurus. Chemosphere. 2008;71(7):1308-1316. doi:10.1016/j.chemosphere. 2007.11.047 
45. He L, Liu Y, Mustapha A, Lin M. Antifungal activity of zinc oxide nanoparticles against Botrytis cinerea and Penicillium expansum. Microbiol Res. 2011;166(3):207-215. doi:10.1016/j.micres.2010.03. 003

46. Lipovsky A, Nitzan Y, Gedanken A, Lubart R. Antifungal activity of $\mathrm{ZnO}$ nanoparticles - the role of ROS mediated cell injury. Nanotechnology. 2011;22(10):105101. doi:10.1088/0957-4484/22/ 10/105101

47. Eskandari M, Haghighi N, Ahmadi V, Haghighi F, Mohammadi SR. Growth and investigation of antifungal properties of $\mathrm{ZnO}$ nanorod arrays on the glass. Physica B. 2011;406(1):112-114. doi:10.1016/j. physb.2010.10.035

48. Kairyte K, Kadys A, Luksiene Z. Antibacterial and antifungal activity of photoactivated $\mathrm{ZnO}$ nanoparticles in suspension. $J$ Photochem Photobiol B. 2013;128:78-84. doi:10.1016/j.jphotobiol. 2013.07.017

49. Leung $\mathrm{YH}$, Chan CMN, Ng AMC, et al. Antibacterial activity of $\mathrm{ZnO}$ nanoparticles with a modified surface under ambient illumination. Nanotechnology. 2012;23(47):475703. doi:10.1088/0957-4484/23/ 47/475703

50. Shinde VV, Dalavi DS, Mali SS, Hong CK, Kim JH, Patil PS. Surfactant free microwave assisted synthesis of $\mathrm{ZnO}$ microspheres: study of their antibacterial activity. Appl Surf Sci. 2014;307:495502. doi:10.1016/j.apsusc.2014.04.064

51. Scott JR, Barnett TC. Surface proteins of gram-positive bacteria and how they get there. Annu Rev Microbiol. 2006;60:397-423. doi:10.1146/annurev.micro.60.080805.142256

52. Cabeen MT, Jacobs-Wagner C. Bacterial cell shape. Nat Rev Microbiol. 2005;3(8):601-610. doi:10.1038/nrmicro1205

53. Tayel AA, El-Tras WF, Moussa S, et al. Antibacterial action of zinc oxide nanoparticles against foodborne pathogens. J Food Saf. 2011;31(2):211-218. doi:10.1111/jfs.2011.31.issue-2

54. Reddy KM, Feris K, Bell J, Wingett DG, Hanley C, Punnoose A. Selective toxicity of zinc oxide nanoparticles to prokaryotic and eukaryotic systems. Appl Phys Lett. 2007;90(21):213902. doi:10.1063/ 1.2742324

55. Clauditz A, Resch A, Wieland K-P, Peschel A, Götz F. Staphyloxanthin plays a role in the fitness of Staphylococcus aureus and its ability to cope with oxidative stress. Infect Immun. 2006;74 (8):4950-4953. doi:10.1128/IAI.00204-06

56. Brown MRW, Allison DG, Gilbert P. Resistance of bacterial biofilms to antibiotics a growth-rate related effect? J Antimicrobial Chemother. 1988;22(6):777-780. doi:10.1093/jac/22.6.777

57. Talebian N, Amininezhad SM, Doudi M. Controllable synthesis of $\mathrm{ZnO}$ nanoparticles and their morphology-dependent antibacterial and optical properties. J Photochem Photobiol B. 2013;120:6673. doi:10.1016/j.jphotobiol.2013.01.004

58. Stanković A, Dimitrijević S, Uskoković D. Influence of size scale and morphology on antibacterial properties of $\mathrm{ZnO}$ powders hydrothemally synthesized using different surface stabilizing agents. Colloids Surf B. 2013;102:21-28. doi:10.1016/j.colsurfb.2012.07.033

59. Dutta RK, Sharma PK, Bhargava R, Kumar N, Pandey AC. Differential susceptibility of Escherichia coli cells toward transition metal-doped and matrix-embedded $\mathrm{ZnO}$ nanoparticles. J Phys Chem B. 2010;114(16):5594-5599. doi:10.1021/jp1004488

60. Jones N, Ray B, Ranjit KT, Manna AC. Antibacterial activity of $\mathrm{ZnO}$ nanoparticle suspensions on a broad spectrum of microorganisms. FEMS Microbiol Lett. 2008;279(1):71-76. doi:10.1111/ j.1574-6968.2007.01012.x

61. Sharma N, Jandaik S, Kumar S. Synergistic activity of doped zinc oxide nanoparticles with antibiotics: ciprofloxacin, ampicillin, fluconazole and amphotericin B against pathogenic microorganisms. Anais Da Academia Brasileira De Ciências. 2016;88:1689-1698. doi:10.1590/0001-3765201620150713
62. Zhang L, Yin L, Wang C, Lun N, Qi Y. Sol- Gel Growth of hexagonal faceted $\mathrm{ZnO}$ prism quantum dots with polar surfaces for enhanced photocatalytic activity. ACS Appl Mater Interfaces. 2010;2(6):1769-1773. doi:10.1021/am100274d

63. Tuomela S, Autio R, Buerki-Thurnherr T, et al. Gene expression profiling of immune-competent human cells exposed to engineered zinc oxide or titanium dioxide nanoparticles. PLoS One. 2013;8(7): e68415. doi:10.1371/journal.pone.0068415

64. Wong SWY, Leung PTY, Djurišić AB, Leung KMY. Toxicities of nano zinc oxide to five marine organisms: influences of aggregate size and ion solubility. Anal Bioanal Chem. 2010;396(2):609-618. doi:10.1007/s00216-009-3249-z

65. Pasquet J, Chevalier Y, Pelletier J, Couval E, Bouvier D, Bolzinger M-A. The contribution of zinc ions to the antimicrobial activity of zinc oxide. Colloids Surf A. 2014;457:263-274. doi:10.1016/j. colsurfa.2014.05.057

66. Ghasemi Y, Peymani P, Afifi S. Quantum dot: magic nanoparticle for imaging, detection and targeting. Acta Bio Medica. 2009;80 (2):156-165

67. Aditya A, Chattopadhyay S, Jha D, Gautam HK, Maiti S, Ganguli M. Zinc oxide nanoparticles dispersed in ionic liquids show high antimicrobial efficacy to skin-specific bacteria. ACS Appl Mater Interfaces. 2018;10(18):15401-15411. doi:10.1021/acsami.8b01463

68. Chen Q, Yakovlev NL. Adsorption and interaction of organosilanes on TiO 2 nanoparticles. Appl Surf Sci. 2010;257(5):1395-1400. doi:10.1016/j.apsusc.2010.08.036

69. Aboulaich A, Tilmaciu C-M, Merlin C, et al. Physicochemical properties and cellular toxicity of (poly) aminoalkoxysilanes-functionalized $\mathrm{ZnO}$ quantum dots. Nanotechnology. 2012;23 (33):335101. doi:10.1088/0957-4484/23/33/335101

70. Jana NR, Earhart C, Ying JY. Synthesis of water-soluble and functionalized nanoparticles by silica coating. Chem Mater. 2007;19(21):5074-5082. doi:10.1021/cm071368z

71. Mitik-Dineva N, Wang J, Truong VK, et al. Escherichia coli, Pseudomonas aeruginosa, and Staphylococcus aureus attachment patterns on glass surfaces with nanoscale roughness. Curr Microbiol. 2009;58(3):268-273. doi:10.1007/s00284-0089320-8

72. Jana TK, Jana SK, Kumar A, et al. The antibacterial and anticancer properties of zinc oxide coated iron oxide nanotextured composites Colloids Surf B. 2019;177:512-519. doi:10.1016/j.colsurfb.2019. 02.041

73. Kumar RS, Sathyamoorthy R, Sudhagar P, Matheswaran P, Hrudhya CP, Kang YS. Effect of aluminum doping on the structural and luminescent properties of $\mathrm{ZnO}$ nanoparticles synthesized by wet chemical method. Physica E. 2011;43(6):1166-1170. doi:10.1016/j.physe.2011.01.022

74. Brehm JU, Winterer M, Hahn H. Synthesis and local structure of doped nanocrystalline zinc oxides. J Appl Phys. 2006;100 (6):064311. doi:10.1063/1.2349430

75. Liu Y, Lian J. Optical and electrical properties of aluminum-doped $\mathrm{ZnO}$ thin films grown by pulsed laser deposition. Appl Surf Sci. 2007;253(7):3727-3730. doi:10.1016/j.apsusc.2006.08.012

76. Bomila R, Suresh S, Srinivasan S. Synthesis, characterization and comparative studies of dual doped $\mathrm{ZnO}$ nanoparticles for photocatalytic applications. J Mater Sci. 2019;30(1):582-592.

77. Bomila R, Srinivasan S, Gunasekaran S, Manikandan A. Enhanced photocatalytic degradation of methylene blue dye, opto-magnetic and antibacterial behaviour of pure and La-doped $\mathrm{ZnO}$ nanoparticles. J Supercond Nov Magn. 2018;31(3):855-864. doi:10.1007/ s10948-017-4261-8

78. Rekha K, Nirmala M, Nair MG, Anukaliani A. Structural, optical, photocatalytic and antibacterial activity of zinc oxide and manganese doped zinc oxide nanoparticles. Physica B. 2010;405 (15):3180-3185. doi:10.1016/j.physb.2010.04.042 
79. Liu Y, Ai K, Yuan Q, Lu L. Fluorescence-enhanced gadolinium-doped zinc oxide quantum dots for magnetic resonance and fluorescence imaging. Biomaterials. 2011;32(4):1185-1192. doi:10.1016/j. biomaterials.2010.10.022

80. Hsu A, Liu F, Leung YH, et al. Is the effect of surface modifying molecules on antibacterial activity universal for a given material? Nanoscale. 2014;6(17):10323-10331. doi:10.1039/c4nr02366h

81. Fakhroueian Z, Dehshiri AM, Katouzian F, Esmaeilzadeh P. In vitro cytotoxic effects of modified zinc oxide quantum dots on breast cancer cell lines (MCF7), colon cancer cell lines (HT29) and various fungi. $J$ Nanopart Res. 2014;16(7):1-14. doi:10.1007/s11051-014-2483-2

82. Banoee $\mathrm{M}$, Seif $\mathrm{S}$, Nazari ZE, et al. ZnO nanoparticles enhanced antibacterial activity of ciprofloxacin against Staphylococcus aureus and Escherichia coli. J Biomed Mater Res Part B. 2010;93 (2):557-561. doi:10.1002/jbm.b.31615

83. Yu J-L, Grinius L, Hooper DC. NorA functions as a multidrug efflux protein in both cytoplasmic membrane vesicles and reconstituted proteoliposomes. J Bacteriol. 2002;184(5):1370-1377. doi:10.1128/jb.184.5.1370-1377.2002

84. Neyfakh AA, Borsch CM, Kaatz GW. Fluoroquinolone resistance protein NorA of Staphylococcus aureus is a multidrug efflux transporter. Antimicrob Agents Chemother. 1993;37(1):128-129. doi:10.1128/ aac.37.1.128

85. Sikong L, Kongreong B, Kantachote D, Sutthisripok W. Photocatalytic activity and antibacterial behavior of Fe3+-doped TiO2/SnO2 nanoparticles. Energy Res J. 2010;1(2):120-125. doi:10.3844/erjsp.2010.120.125

86. Patel MN, Chhasatia MR, Gandhi DS. DNA-interaction and in vitro antimicrobial studies of some mixed-ligand complexes of cobalt (II) with fluoroquinolone antibacterial agent ciprofloxacin and some neutral bidentate ligands. Bioorg Med Chem Lett. 2009;19 (10):2870-2873. doi:10.1016/j.bmcl.2009.03.078

87. Ravichandran K, Chidhambaram N, Gobalakrishnan S. Copper and Graphene activated $\mathrm{ZnO}$ nanopowders for enhanced photocatalytic and antibacterial activities. J Phys Chem Solids. 2016;93:82-90. doi:10.1016/j.jpcs.2016.02.013

88. Kumar V, Prakash J, Singh JP, et al. Role of silver doping on the defects related photoluminescence and antibacterial behaviour of zinc oxide nanoparticles. Colloids Surf B. 2017;159:191-199. doi:10.1016/j.colsurfb.2017.07.071

89. Bechambi O, Chalbi M, Najjar W, Sayadi S. Photocatalytic activity of $\mathrm{ZnO}$ doped with $\mathrm{Ag}$ on the degradation of endocrine disrupting under UV irradiation and the investigation of its antibacterial activity. Appl Surf Sci. 2015;347:414 420. doi:10.1016/j.apsusc.2015.03.049

90. Sehmi SK, Noimark S, Pike SD, et al. Enhancing the antibacterial activity of light-activated surfaces containing crystal violet and $\mathrm{ZnO}$ nanoparticles: investigation of nanoparticle size, capping ligand, and dopants. ACS Omega. 2016;1(3):334-343. doi:10.1021/acsomega.6b00017
91. Hameed ASH, Karthikeyan C, Ahamed AP, et al. In vitro antibacterial activity of $\mathrm{ZnO}$ and $\mathrm{Nd}$ doped $\mathrm{ZnO}$ nanoparticles against ESBL producing Escherichia coli and Klebsiella pneumoniae. Sci Rep. 2016;6:24312. doi:10.1038/srep24312

92. Shanmugam V, Jeyaperumal KS. Investigations of visible light driven $\mathrm{Sn}$ and $\mathrm{Cu}$ doped $\mathrm{ZnO}$ hybrid nanoparticles for photocatalytic performance and antibacterial activity. Appl Surf Sci. 2018;449:617-630. doi:10.1016/j.apsusc.2017.11.167

93. Farouk A, Moussa S, Ulbricht M, Schollmeyer E, Textor T. ZnOmodified hybrid polymers as an antibacterial finish for textiles. Textile Res J. 2014;84(1):40-51. doi:10.1177/0040517513485623

94. Spanhel L, Anderson MA. Semiconductor clusters in the sol-gel process: quantized aggregation, gelation, and crystal growth in concentrated zinc oxide colloids. J Am Chem Soc. 1991;113 (8):2826-2833. doi:10.1021/ja00008a004

95. Li YN, Xu WM, Zhang GQ. Effect of Coupling Agent on Nano-Zno Modification and Antibacterial Activity of Zno/HDPE Nanocomposite Films. IOP Publishing; 2015:012054.

96. Soumya S, Kumar SN, Mohamed AP, Ananthakumar S. Silanated nano $\mathrm{ZnO}$ hybrid embedded PMMA polymer coatings on cotton fabrics for near-IR reflective, antifungal cool-textiles. New J Chem. 2016;40(8):7210-7221. doi:10.1039/C6NJ00353B

97. Kamonkhantikul K, Arksornnukit M, Takahashi H. Antifungal, optical, and mechanical properties of polymethylmethacrylate material incorporated with silanized zinc oxide nanoparticles. Int J Nanomedicine. 2017;12:2353. doi:10.2147/IJN.S132116

98. Čepin M, Jovanovski V, Podlogar M, Orel ZC. Amino-and ionic liquid-functionalised nanocrystalline $\mathrm{ZnO}$ via silane anchoring-an antimicrobial synergy. J Mater Chem B. 2015;3(6):1059-1067. doi:10.1039/C4TB01300J

99. Milović NM, Wang J, Lewis K, Klibanov AM. Immobilized Nalkylated polyethylenimine avidly kills bacteria by rupturing cell membranes with no resistance developed. Biotechnol Bioeng. 2005;90(6):715-722. doi:10.1002/bit.20454

100. Ozkan E, Ozkan FT, Allan E, Parkin IP. The use of zinc oxide nanoparticles to enhance the antibacterial properties of light-activated polydimethylsiloxane containing crystal violet. RSC Adv. 2015;5(12):8806-8813. doi:10.1039/C4RA13649G

101. Jaramillo AF, Baez-Cruz R, Montoya LF, et al. Estimation of the surface interaction mechanism of $\mathrm{ZnO}$ nanoparticles modified with organosilane groups by Raman spectroscopy. Ceram Int. 2017;43 (15):11838-11847. doi:10.1016/j.ceramint.2017.06.027
International Journal of Nanomedicine

\section{Publish your work in this journal}

The International Journal of Nanomedicine is an international, peerreviewed journal focusing on the application of nanotechnology in diagnostics, therapeutics, and drug delivery systems throughout the biomedical field. This journal is indexed on PubMed Central, MedLine, CAS, SciSearch ${ }^{\mathbb{R}}$, Current Contents ${ }^{\mathbb{R}} /$ Clinical Medicine, $^{2}$
Journal Citation Reports/Science Edition, EMBase, Scopus and the Elsevier Bibliographic databases. The manuscript management system is completely online and includes a very quick and fair peer-review system, which is all easy to use. Visit http://www.dovepress.com/ testimonials.php to read real quotes from published authors. 